\title{
PEMBENTUKAN KONSEP DIRI ANAK MELALUI KOMUNIKASI DAKWAH
}

\author{
Nofha Rina \\ Program Studi Ilmu Komunikasi Fakultas Komunikasi dan Bisnis Telkom University \\ Jl. Telekomunikasi No. 1, Kota Bandung, nofharina80@gmail.com
}

\begin{abstract}
ABSTRAK
Orangtua memiliki peran utama dalam membentuk konsep diri anak yang memiliki hubungan dengan agama dan masyarakat. Agama sebagai pondasi awal dalam memaknai kehidupan agar dapat menyelamatkan diri di dunia. Jalinan komunikasi yang terjadi antara orangtua dan anak adalah untuk membangun hubungan antarpersonal yang baik. Pembentukan konsep diri anak bermula dari penilaian orangtua terhadap anak dimana orangtua sebagai komunikator dakwah untuk mengajarkan nilai keagamaan. Pola komunikasi dakwah menjadi hal yang diperhatikan dalam menyampaikan dakwah diantaranya yaitu: berbicara langsung apa yang dipikirkan (imprompiu remark), membaca naskah (reading from manuscript), menghafal (memorizing the speech), dan memaparkan dengan menggunakan catatan garis besarnya (delivering extemporaneously). Metode yang digunakan dalam tulisan ini adalah fenomenologis dimana mencoba mencari arti dari pengalaman dalam kehidupan. Dimana tujuannya dalah menemukan makna dari hal yang esensial dari pengalaman seseorang melalui wawancara mendalam terhadap partisipan. Sehingga hasil yang diperoleh adanya pemaknaan terhadap persepsi dan sikap partisipan terhadap pengalaman hidup sehari-hari.
\end{abstract}

Kata kunci : Orangtua, Konsep Diri Anak, Pola Komunikasi Dakwah 


\section{PENDAHULUAN}

Manusia terlahir sebagai makhluk ciptaan Tuhan yang pada awalnya memiliki fitrah yang suci secara batiniah sehingga terjaga dari berbagai bentuk dosa dalam bentuk apapun. Pemahaman mengenai agama yang dianutnya pada mulanya diperkenalkan melalui lingkungan terdekatnya yaitu keluarga. Peranan orangtua sebagai "jembatan" dalam memahami agama memiliki porsi yang cukup besar karena sebagai pondasi awal untuk menanamkan dan menerapkan nilai-nilai agama yang dipahami dan diyakininya (iman).

Komunikasi antar anggota keluarga sebagai pondasi awal dalam memperkenalkan nilai dan norma agama yang benar sehingga harus dilaksanakan agar pesan-pesan agama yang disampaikan dapat diterima oleh semua anggota. Komunikasi pada hakikatnya merupakan suatu proses yang dilakukan oleh seseorang (orangtua) kepada orang lain (anak-anak) dengan menggunakan media yang efektif agar dapat menghasilkan kesamaan persepsi dan pemahaman serta dapat meminimalisisr misscommunication diantara mereka.

Adapun kewajiban orangua dalam memperkenalkan, mengajarkan, mendidik, dan menerapkan nilai-nilai agama bagi semua anggota keluarga tanpa terkecuali dicantumkan salah satunya dalam Surat At Tahrim:66 yaitu:

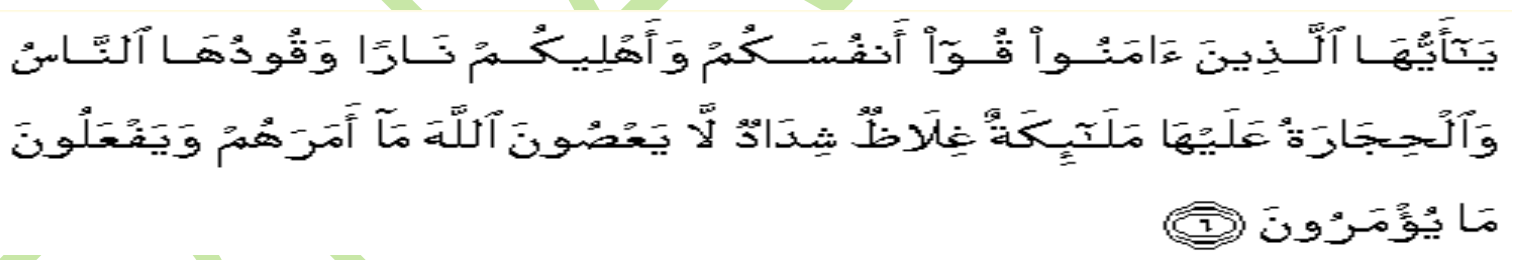

Artinya:

Hai orang-orang yang beriman, peliharalah dirimu dan keluargamu dari api neraka yang bahan bakarnya adalah manusia dan batu; penjaganya malaikat-malaikat yang kasar, keras, dan tidak mendurhakai Allah terhadap apa yang diperintahkan-Nya kepada mereka dan selalu mengerjakan apa yang diperintahkan.

Maka jelas ditekankan dalam surat tersebut bahwa kewajiban orangtua dalam mengkomunikasikan nilai-nilai agama kepada keluarga inti adalah hal yang benar karena peran utama orangtua adalah memelihara, menjaga, dan menyelamatkan keluarganya dari ancaman api neraka kelak diakhir jaman. Disebabkan penekanan ayat tersebut bersifat wajib maka hendaknya para orangtua tidak mengingkari perintah teersebut dan melaksanakannya dengan penuh kesungguhan. 


\section{Peran Orangtua Sebagai Komunikator Dakwah}

Dalam dunia komunikasi peran komunikator memiliki peran yang penting agar dapat menyukseskan kesamaan persepsi melalui pesan yang disampaikan kepada komunikan. Hal serupa dapat diterapkan melalui orangtua sebagai komunikator dalam menyampaikan pesan-pesan keagamaan kepada anak-anak. Orangtua memiliki kewajiban untuk mengasuh anak-anak mereka sejak dilahirkan dimana definisi pengasuhan berdasarkan ahli fikih dalam buku Ringkasan Fikih Sunnah yang ditulis oleh Sayyid Sabiq (2014:581) berasal dari kata hadhanah sebagai pemeliharaan terhadap anak yang masih kecil, belum mummayiz, laki-laki maupun perempuan, belum bisa mengurus dirinya sendiri, dan menjaga diri dari hal-hal yang bisa menyakiti dan membahayakan, mendidiknya secara jasmani , kejiwaan dan akal.

Maka selayaknya orangtua memberikan peran yang cukup besar bagi dirinya dalam mendidik anak-anak mereka dikarenakan anak-anak tersebut memiliki kekurangan baik secara akal ataupun jiwanya (nafsiah) dalam memahami dan menerapkan nilai-nilai keagamaan. Dikarenakan orangtua sebagai komunikator dalam menyampaikan nilai-nilai keagamaan maka orangtua harus memiliki kemampuan untuk melakukan persuasi kepada anak-anak untuk dapat mengajak mereka dalam jalan kebenaran.

"Secara semantik, dakwah (da'wah) berarti ajakan, seruan, dan panggilan" menurut Ma'luf dalam Ma'arif (2010:33). Sehingga kemampuan persuasi dalam bentuk ajakan dan seruan harus dilakukan melalui pesan yang disampaikan dengan metode yang benar agar dapat dipahami dan dapat menyelamatkan anak-anak dari berbagai dosa dunia. Upaya orangtua sebagai komunikator dakwah bagi keluarganya harus dimulai dari pembinaan terhadap diri mereka sendiri karena dalam melakukan dakwah dibutuhkan contoh teladan dalam diri orangtua yang akan ditiru oleh sang anak.

Pembentukan pribadi orangtua yang teladan dimulai dengan memiliki aqidah yang tauhid dan berakhlak mulia (akhlakul karimah). Menurut Safe'i dalam Ma'aruf (2010:34) dinyatakan bahwa

"Dakwah berupaya untuk membawa masyarakat kearah kebajikan yang dinamis dan seimbang dengan menegakkan dan menyempurnakan kepribadianyang ber-alkhlakul karimah. Dakwah merupakan suatu proses internalisasi, transmisi, difusi, institusionalisasi dan transformasi Islam yang melibatkan, antara lain komunikator dakwah (dai), komunikan dakwah (mad'u), pesan, konteks, dan respon untuk mewujudkan kehidupan yang lebih baik, selamat dunia dan akhirat".

Sehingga keteladanan kepribadian dalam diri orangtua sebagai komunikator dakwah tidak dapat diabaikan begitu saja karena sebagai contoh utama bagi anak-anak. Nilai-nilai agama yang disampaikan 
bersifat menyeluruh karena segala ajaran yang diperintahkan oleh Allah di dalam Al Quran merupakan pijakan utama dalam bersikap dan berperilaku.

Komunikasi dakwah yang cair dari orangtua kepada anak tetap ditonjolkan agar dapat lebih komunikatif dan mengurangi hambatan-hambatan yang terjadi baik secara internal ataupun secara eksternal dalam diri orangtua, anak, dan lingkungan sekitar. Kenyamanan dan kejernihan hati dalam diri anggota keluarga dapat membentuk pribadi yang berkualitas dan meningkatkan konsep diri anak agar dapat menjalankan nilai-nilai keagamaan secara komprehensif. Faktor lingkungan merupakan hal yang tidak dapat dihindari karena sangat dekat dengan keseharian kita akan tetapi hal-hal yang bersifat negatif dapat diatassi jika pondasi keyakinan (iman) setiap anggota telah mengakar begitu kuat didalam diri. Agama sebagai pondasi utama dalam mengatasi dan menjawab solusi segala permasalahan hidup seseorang.

Peran orangtua sebagai tokoh komunikator dakwah sebagai sentral penting karena apabila seorang tokoh dakwah yang memiliki kekotoran secaraa jiwa (nafsiah) tidak dapat menggugah hati anak-anak mereka untuk mengikuti apa yang dikatakan dan diajarkannya. Sehingga kelebihan yang dimiliki baik secara keilmuan agama dan umum, perbuatan yang baik, dan bersikap yang mulia menjadi ukuran utama bagi para orangtua agar dapat menyentuh jiwa sang anak. Lebih jauh lagi dapat mewujudkannya dalam kehidupan yang nyata baik secara pemahaman dan tindakan yang sesungguhnya.

Kredibilitas orangtua sebagai komunikator menjadi salah satu poin tersendiri dihadapan anakanak untuk menunjang keberhasilan dakwah didalam rumah tangga. Efektivtas pesan yang disampaikan, media yang tepat dalam menyampaikan pesan dakwah, kesamaan tujuan, persepsi dan pemahaman yang sama dapat menjadikan keberhasilan dakwah yang dilakukan orangtua berjalan efektif.

Menurut Ishlahi dalam Ma'aruf (2010:41) ada beberapa syarat dan sifat tertentu yang dimiliki oleh komunikator dakwah yaitu: (1). Tulus ikhlas meyakini kebenaran agama, (2). Memberi kesaksian pada agama yang mereka imani dengan menyatakannya secara tegas, (3). Memberi contoh, (4). Dakwah Islam harus ditempatkan diatas prasangka-prasangka kebangsaan dan kelompok, (5). Kesaksian harus mencakup seluruh kebenaran yang diwahyukan Tuhan, (6). Sabar, tabah, dan rela berkorban meski dengan jiwa dan raganya. Selain itu ditambahkan juga menurut Al-Rifa'i dalam Ma'aruf (2010:41) (7). Menguasai ilmu, (8). Menempuh cara hikmah bagi yang terpelajar dan maw'idhah bagi orang awam, (9). Lembut dalam menyampaikan nilai-nilai dan pandangan, (10). Mengetahui tabiat kejiwaan komunikannya dengan memperhatikan apa yang mereka inginkan. 


\section{Konsep Diri Anak}

Komunikasi antara orangtua dan anak serta dimainkannya peran orangtua menjadi kesatuan yang tak terpisahkan satu sama lainnya dikarenakan kedua hal diatas dapat membantu anak dalam menemukan konsep dirinya. Keluarga merupakan lingkungan terdekat dari diri sang anak dalam pembentukan karakter, sikap, kepribadian dirinya sehingga tidak dapat dipungkiri tanggungjawab orangtua begitu besar dalam membimbing dan mengarahkan anak-anak.

Anak akan melihat dirinya berdasarkan apa yang dikatakan orang lain diluar dirinya, anak akan bercermin pada dirinya sudah pantaskah saya menjadi anak yang dapat membanggakan kedua orangtua saya sesuai dengan yang mereka harapkan, atau anak akan membayangkan seperti apakah dirinya dihadapan orang lain. Segala bentuk tanya dalam diri anak dengan mengamati dirinya sendiri dan dapat menyimpulkan penilaian terhadap dirinya maka hal ini disebut sebagai konsep diri. Rahmat (2003:99) menyatakan bahwa "Dengan mengamati diri kita, sampailah kita pada gambaran dan penilaian diri kita. Ini disebut konsep diri."

Pada saat memahami dan menilai diri sendiri tetapi tanpa diiringi dengan pondasi agama yang kuat maka akan membentuk kepribadian yang cukup rapuh dalam menghadapi problema kehidupan yang semakin hari semakin banyak dan membutuhkan kepribadian yang tangguh dalam mengatassi permasalahan serta mencari solusi didalamnya. Pada saat orangtua memberikan penilaian yang baik atau postif terhadap anak melalui pembinaan keagamaan yang kuat dalam dakwh dan dapat menanamkan keyakinan (iman) yang tauhid dalam dirinya maka anak akan mengenal dan menilai dirinya sesuai dengan apa yang digambarkan oleh orangtuanya. Dia akan berusaha mempertahankan citra diri (self-image) yang positif karena saat orangtua mengatakan "kamu anak soleh, cerdas, pintar" maka dia harus berhasil seperti yang dikatakan orangtuanya. Hal inilah yang akan membentuk konsep diri anak karena pujian dan penghargaan orangtua kepada dirinya.

Orangtua dengan memberikan contoh yang tauladan, melakukan keihklasan dalam menjalankan aturan agama dengan benar, sabar dan mau berkorban untuk tiada henti mengarahkan anak pada jalan kebenaran sesuai dengan apa yang diimaninya, dapat memahami ilmu agama dengan baik, dan mengetahui kejiwaan anak dengan memperhatikan apa yang anak pikirkan dan butuhkan maka akan membentuk situasi dan kondisi yang kondusif untuk melahirkan konsep diri yang positif bagi anak tersebut. Harry Stack Sullivan dalam Rahmat (2003:101) mengatakan bahwa "jika kita diterima orang lain, dihormati, dan disenangi karena keadaan diri kita, kita akan cenderungbersikap 
menghormati dan menerima diri kita. Sebaliknya, bila orang lain selalu meremehkan kita, menyalahkan kita dan menolak kita, kita akan cenderung tidak akan menyenangi diri kita."

Berdasarkan pernyataan yang dikemukakan oleh Harry diatas akan ada suasana dimana orang tua akan menganggap remeh terhadap diri anak, menyalahkan jika anak berbuat salah serta menolak kehadiran dirinya dilingkungan keluarga sehingga akan menimbulkan perasaan sedih. Perasaan sedih akan membuat konsep dirinya menuju kearah yang negatif karena tidak membangun rasa percaya dirinya. Padahal ketika ingin mengajak anak untuk menjalankan hidup sesuai aturan agama dibutuhkan suasana yang mendukung agar anak dapat mengembangkan kepercayaan dirinya berdasarkan iman yang dimiliki, seperti yang tercantum pada Surat Al Imran:139 yaitu:

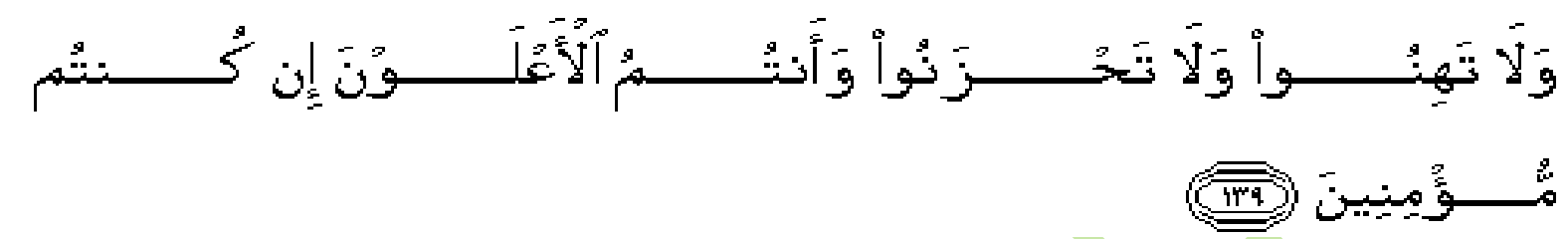

Artinya:

Janganlah kamu bersikap lemah, dan janganlah (pula) kamu bersedih hati, padahal kamulah orangorang yang paling tinggi (derajatnya), jika kamu orang-orang yang beriman

Maka peran orangtua sangatlah menjadi penting dan memiliki pengaruh yang kuat terhadap diri anak dimana George Herbert dalam Rahmat (2003:101) menyebut orangtua sebagai significant others (orang lain yang sangat penting). Bentuk pujian, penghargaan, kehangatan keluarga akan menjadikan konsep diri anak menjadi positif dan sebaliknya cacian, makian, bentakan kemarahan akan membuat akan memiliki konsep diri yang negatif.

Orangtua yang memberikan tindakan yang baik, mengarahkan pikiran anak dengan benar dan mengasihi anak secara ikatan emosional akan sangat menjadikan anak untuk bertingkah laku sesuai dengan konsep diri positif yang disebut sebagai nubuat yang diperoleh sendiri. Selain itu anak akan cenderung bersifat terbuka atau mau membuka diri dalam menerima keadaan dilingkungannya, memiliki pemikiran yang terbuka terhadap ide-ide dan gagasan yang baru yang dapat mengembangkan dirinya dan mau menerima pandangan orang lain. Meningkatkan kepercayaan diri (self confidence) akan menjadikan dirinya dapat bergaul dengan baik, mampu berkomunikasi secara aktif dan dapat menerima situasi komunikasi, memiliki tingkat relevansi antara yang dikatakan dengan yang dilakukan atau dilihatnya. Sehingga akan mengarahkan perilaku anak pada hal yang positif dengan menjadikan dirinya sebagai muslin yang baik, akan banyak mengkaji agama melalui buku-buku keagmaan, 
menghadiri kegiatan keagamaan, dan lain sebagainya. Maka anak akan melakukan selektivitas dalam dirinya.

\section{Pola Komunikasi Dakwah}

Siahaan dalam Ma'aruf (2010:78) mengatakan "Pola menyangkut pesan yang terkait dengan situasi dan kondisi yang mengacu pada 'sesuatuyang membungkus inti pesan itu sendiri'. Pola memberikan data untuk memahami dan mengerti tindakan atau tingkah laku seseorang." Maka pola komunikasi yang akan dilakukan disesuaikan dengan kondisi komunikan saat dilakukannya interaksi, orangtua akan menyesuaikan pesan dakwah yang akan dsampaikan sesuai dengan kejiwaan, kemampuan, perasaan yang ada dalam diri anak.

Ada beberapa faktor yang yang dapat membentuk pola komunikasi yaitu seseorang akan melakukan pola komunikasi dikarenakan dirinya memiliki banyak pengalaman yang telah dialaminya sehingga melalui pengalaman akan membentuk kebiasaan tertentu yang akan dijadikan referensi dalam membuat pola komunikasi dalam dirinya, pendidikan dan pengalaman hidup merupakan beberapa faktor yang dapat dijadikan sebagai kapasitas diri seseorang dalam menyampaikan komunikasi, dan tujuan komunikasi yang dilakukan akan memebawa dirinya membentuk pesan, menggunakan media dan metode yang khas agar apa yang disampaikan dapat tercapai dengan baik.

Sehingga dari faktor-faktor diatas maka orangtua dapat melakukan pola komunikasi kepada anak dalam menyampaikan dakwahnya sesuai dengan pengalaman hidup yang telah dimilikinya sehingga memberikan pengarahn, pendidikan, pola pikir yang benar akan menjadikan konsep diri anak menjadi positif. Dikarenakan orangtua akan memberikan arahan dan penghargaan yang benar dan akan mengesampingkan pengalaman hidup yang buruk yang pernah dialaminya. Faktor pendidikan yang dimiliki akan memotivasi anak gara dapat menjadi pribadi yang lebih baik dari diri orangtua sehingga kapasitas diri orangtua dalam menyampaikan pesan tidak lepas dari pendidikan yang telah dienyam selama hidup, dan tidak kalah pentingnya orangtua akan memainkan perannya ketika apa yang menjadi maksud dan tujuan dirinya dalam memberikan dakwah kepada anaknya akan disesuaikan dengan bahasa yang digunakan, gerakan tubuh yang dapat menyentuh emosional anak secara perlahan, media komunikasi baik dengan lisan ataupun menggunakan media elektronik dalam mengajarkan nilai-nilai keagamaan kepada anak, serta dapat menggunakan cara yang tepat agara anak mau mengikuti apa yang diajarkan dan diharapkan.

Sentuhan-sentuhan secara verbal dan nonverbal dari orangtua sebagai komunikator dakwah memiliki peran yang tidak mudah karena nilai-nilai keagamaan dalam membentuk konsep diri anak 
harus dapat menyentuh nilai sosial, agama, budaya yang ada didalam dirinya, lingkungan sekitar, dan masyarakat pada umumnya. Mengapa dibutuhkan hal-hal tersebut? Hal ini dimaksudkan agar nilainilai kegamaan yang terkait dengan dakwah dapat dipahami, diterima, dan mengurangi konflik batin dan fisik dalam diri anak. Anak sangat rentan dengan sifat krtis yang dimiliki sehingga segala pertanyaan, penolakan terhadap hal-hal yang tidak sesuai dengan apa yang dipahami dan pikirkan dalam dirinya berdasarkan pengalama hidupnya akan terlontarkan secara verbal dan nonverbal. Sehingga situasi dan kondisi harus dapat dikuasai oleh orangtua sebagai significant others.

Dalam Ma'arif (2010:79) dikatakan bahwa untuk kepentingan retorika, seoarng pembicara (komunikator) dapat mempergunakan empat (4) pola komunikasi dakwah yaitu: (1). Berbicara langsung apa yang dipikirkan (imprompiu remark), (2). Membaca naskah (reading from manuscript), (3). Menghafal (memorizing the speech), dan (4). Memaparkan dengan menggunakan catatan garis besarnya (delivering extemporaneously).

\section{Metode Penelitian}

Adapun metode yang digunakan dalam tulisan ini adalah studi fenomenologis yang melalui kajian penelitian (metode pencarian). Dimana penulis menghimpun konsep yang terkait dengan orang sebagai komunikator dakwah dalam membentuk konsep diri anak melalui pengalaman hidup, sikap, pendapat dari partisipan dengan menggunakan jenis pola komunikasi dakwah apa saja yang telah diterapkan dalam keluarga. Sehingga dapat memberikan makna terhadap pengalaman dalam kehidupan partisipan tersebut. Tujuan dilakukannya studi fenomenologis terhadap tulisan ini agar dapat menemukan hal-hal yang bersifat esensial atau mendasar melalui wawancara (interview) yang mendalam dengan partisipan. Adapun partisipan dalam penelitian ini adalah beberapa orangtua yang memainkan peran sebagai ayah atau ibu dalam memberikan pendidikan secara intens kepada anakanak dalam kehidupan keluarga dan anak-anak yang memberikan penilaian terhadap diri mereka setelah dibina melalui kegiatan dakwah yang dilakukan oleh orangtua mereka.

Persepsi dan sikap para partisipan melalui wawancara sangat erat kaitannya dengan latar belakang pendidikan yang dimiliki, pengalaman hidup yang pernah dilalui di masa sebelumnya, serta kejadian terkini yang dihadapi dalam menghadapi anak yang memiliki konsep diri postif dan negatif. Penekanan pendekatan dilihat dari aspek subjektif dari perilaku yang ditonjolkan oleh partisipan, lalu memehami bagaimana partisipan memberi makna terhadap peristiwa yang terjaid dikehidupannya. Sehingga melalui cara pendekatan tersebut diketahui bagaimana cara manusia menginterpretasikan pengalamannya lewat interaksi oranglain.

\section{Hasil dan Pembahasan}


Orangtua sangat andil dalam membentuk konspe diri anak maka terkait dengan hal tersebut tidak ada salahnya penulis merangkai bagaimana pola komunikasi dakwah yang dilakukan partisipan dalam membentuk konsep diri anak dalam keluarga dan pandangan anak mengenai konsep diri mereka sendiri dari hasil pendidikan di keluarganya. Ada berbagai hal yang dilakukan oleh orangtua dalam menerapkan empat (4) pola komunikasi dakwah kepada anak yaitu:

Berbicara langsung apa yang dipikirkan (imprompiu remark) dimana cara ini diterapkan oleh partisipan dengan usia yang cukup lansia dalam mendidik anak-anaknya. Dengan usia yang tidak muda dan produktif lagi, seorang ibu yang memiliki latar belakang pendidikan pendidikan dasar mengemukakan bahwa cara mengarahkan dan mendidik anak secara langsung dan hanya mengeluarkan apa yang ada dalam pikirannya semata. Keterbatasana pengalam hidup dalam mendidik anak dikarenakan tidak begitu memahami pola pengasuhan dan komunikasi kepada anak secara baik, terkadang penggunaan bahasa yang diberikan sangat emosional.

Disaat beliau memainkan perannya sebagai orangtua yang memiliki kewajiban untuk mendidik anak-anak maka pada saat anak melakukan kesalahan da tidak menuruti apa yang dikehendaki orangtua dalam pemberian niai agama maka ucapan yang diungkapkan terkadang bersifat cemoohan, kata-kata yang negatif yang membuat konflik sering dialami dalam keluarganya. Anak-anak yang didik telah memasuki usia remaja dan dewasa sehingga konsep diri yang tertanam dalam diri anak cenderung negatif. Anak menjadi tidak ingin berkomunikasi lebih lanjut dengan orangtua, membatasi diri dengan keluarga, tidak memiliki kepercayaan diri, tidak mampu berkomunikasi secara lugas kepada lingkungan karena merasa khawatir takut salah. Sehingga pola komunikasi dakwah yang dapat membaw adan membentuk konsep diri positif berbalik secara nyata.

Maka peran orangtua yang diharapkan dapat memberikan pengayoman terhadap diri anak memberikan kesenjangan yang cukup besar. Sehingga untuk mengatasi permasalahan tersebut diperlukan proses pembentukan kepribadian yang tauladan dalam diri orangtua dengan lebih membuka diri dalam pengarahan, memiliki keinginan untuk dapat mengkaji ilmu lebih banyak lagi diusia yang lansia dengan mengikuti kegiatan keagamaan dalam mengubah pola pikir, perilaku, dan sikap sebagai orangtua.

Hal ini telah dilakukan oleh partsipan (ibu) untuk mengubah cara dalam memberikan dakwah kepada anak-anaknya dan telah berupaya untuk memberikan perubahan secara maksimal dalam menerapkan pola komunikasi dakwah yang terkait dengan imprompiu remark. Keterbatasan dalam membaca dan menghafal menjadikan dirinya untuk dapat melihat dan mendengarkan saja kajiankajian yang terkait dengan peran orangtua dalam membentuk konsep diri anak sehingga apa yang 
dicerna dalam pikirannya langsung dipraktekkan dalam kehidupan nyata. Cukup efektif dalam mengatasi problematika dengan anak terkait penyampaian dakwah.

Pola yang selanjutnya mengenai membaca naskah (reading from manuscript), dimana setiap pribadi memiliki keunggulan tersendiri dalam menerapkan pola komunikasi dakwah melalui pengembangan wawasan pengetahuan untuk aktif membaca materi-materi dakwah yang akan disampaikan kepada anak. Seorang ayah yang berusia produktif mengetahui bahwa potensi dirinya yang unggul dalam membaca menjadikan dirinya untuk lebih paham bagaimana berkomunikasi kepada anak dengan karakteristik anak yang masih remaja. Profesi pendakwah yang diemban dirinya harus dapat dipraktekkan secara langsung dari beberapa materi yang disampaikan. Sehingga membaca naskah merupakan poin utama yang harus dilakukan agar materi yang disampaikan dapat dipahami secara komprehensif dan meminimalisir ketdakpahaman. Maka ketika adanya kesesuaian antara materi yang diberikan, perilaku seorang ayah dalam memberikan pujian atau reward kepada anak selaras dengan apa yang diharapkan oleh anaknya. Relevansi antara teori dan praktik yang dilakukan oleh orangtuanya membuat anak menjadi percaya diri, mampu berkomunikasi dengan baik antar anggota keluarga, sahabatnya, dan lingkunganya, mampu menerima gagasan yang dapat membuat dirinya nyaman untuk berbuat lebih baik lagi. Sehingga anak memandang dirinya memiliki potensi yang positif dalam melakukan berbagai aktifitas dalam kehidupannya. Sehingga konsep diri positif membentuk dirinya menjadi pribadi yang diharapkan oleh orangtua dan lingkungannya. Anak akan memiliki motivasi yang besar dalam mengkaji keagamaan melalui kegiatan-kegiatan yang diikuti, rajin membaca buku keagamaan sehingga dirinya akan terkena terpaan selektif.

Pola yang terkait dengan menghafal (memorizing the speech), memberikan keleluasaan yang besar dalam menyampaikan diri dalam berdakwah yang mampu mencerna secara praktis dari apa saja yang hendak disampaikan. Hal ini terjadi pada ibu yang berusia poduktif dimana latar belakang pendidikannya hingga menengah atas tetapi mampu mengkaji materi dakwah dengan terampil dan mampu menyampaikannya dengan lugas tanpa terpaku secara teks. Pembinaan yang diberikan kepada anak dapat secara cepat menyentuh aspek psikologis (batiniah) sang anak yang berusia remaja. Intensitas menghafal yang bagus ditambah dengan membaca kajian-kajian materi keagamaan yang terkait dengan dakwah secara optimal mampu mengurangi kesulitan ketika berdakwah. Akan tetapi meskipun potensi orangtua dan telah memainkan perannya secara maksimal akan tetapi diri anak belum mampu untuk menerima apa-apa yang disampaikan oleh ibu tersebut.

Sehingga diperlukannya bantuan untuk dapat mengarahkan anak tersebut dengan melakukan kerjasama dengan ayahnya. Kerjasama yang terjalin antar orangtua dapat meminimalisir problema yang dihadapi. Makna yang tersirat dalam kehidupan keluarga sangat erat dengan peristiwa yang telah 
dialami oleh keluarga itu sendiri. Kejadian peristiwa yang dialami akan memberikan kesan tersendiri bagi anak dalam membentuk konsep dirinya. Proses selektivitas akan terjadi pada anak tergantung pada konsep diri yang melekat pada dirinya. Anak cenderung mempersepsi hal-hal yang negatif atau positif yang orang berikan pada dirinya. Jika memiliki konsep diri negatif maka anak akan menilai dirinya sebagai anak yang tidak berguna, nakal dan akan mengabaikan pujian dari orang lain sehingga akan berpengaruh pada persepsi selektif pada dirinya.

Pola yang terakhir yang digunakan dalam komunikasi dakwah yaitu memaparkan dengan menggunakan catatan garis besarnya (delivering extemporaneous/y). Dimana orangtua dapat menjelaskan lebih komprehensif dengan garis-garis besar yang menjadi hal-hal esensial yang harus disampaikan kepada anak. Catatan garis besar ini dapat membuat orangtua dan anak lebih optimal dalam pengembangan praktis. Ketika anak paham secara langsung apa yang menjadi garis besar bahasan yang dikomunikasikan maka akan melatih ingatan selektif dalam dirinya dimana dirinya akan mengingat hal-hal apa yang menjadi pusat perhatian dalam pikirannya yang dijadikan referensi hidup dalam menjadi pribadi yang cerdas, taat beragama, dan pribadi yang menyenangkan bagi semua orang dan tidak ingat terhadap hal-hal diluar yang dipahaminya. Hal ini terjadi pada anak-anak remaja yang duduk di sekolah emnengah atas yang memiliki konsep diri postif dan negatif.

Anak tersebut akan mengingat apa yang menjadi garis besar dalam hidupnya untuk menjadi pribadi yang soleh, cerdas, dan lainnya yang bersifat positif secara teoritis dan praktis. Misalkan anak dapat mengingat buku psikologi komunikasi karya $A$ tetapi tidak ingat dengan buku psikologi komunikasi karya lainnya. Sehingga dirinya akan berkutat pada hal-hal apa saja yang harus dilakukan dalam membentuk konsep diri positif yang sesuai dengan penilaian orangtua terhadap dirinya. Sebaliknya anak yang memiliki konsep diri negatif dia akan fokus pada apa yang menjadi pencitraan negatif dari orang lain. la akan ingat akan kata-kata hinaan yang dikemukakan oleh B dan tidak ingat dengan kata-kata lainnya yang dikemukakan orang lainnya. Sehingga kata-kata hinaan dibuat sebagai lambang terjemahan dari apa yanga da dalam pikirannya. Jika dirinya merasa bahwa dia adalah anak yang nakal dan menyebalkan maka akan mengeluarkan kata-kata hinaan atau pepatah negatif tertentu dan menghindari penggunaan kata-kata atau pepatah lainnya. Dia akan menggunakan gerakan tubuh, wajah, atau hal lainnya yang sesuai dengan konsep dirinya sebagai anak nakal. Hal ini dalam kajian psikologi komunikasi disebut sebagai penyandian selektif.

\section{KESIMPULAN}

Melalui hasil dan pembahasan diatas dapat diuraikan bahwa menjalankan peran orangtua dalam membentuk konsep diri anak baik itu negatif atau positif melalui pola komunikasi dakwah memilki model tersendiri. Uraian pesan-pesan yang disampaikan mengacu pada pembersihan hati, 
kesadaran diri dan batiniah untuk melahirkan sikap dan perilaku yang teladan secara berkelanjutan. Pesan-pesan yang disampaikan orangtua yang bersifat emosional mampu membentuk kepribadian anak dengan membuka forum kesempatan untuk dialog interaktif dalam membuka wawasana (kognitif) dan menyentuh perasaan (afektif) anak dalam membentuk konsep diri anak. Berpikir kritis mampu membina mental para anak-anak dalam keluarga untuk menjadii pribadi yang tangguh dengan memberikan informasi baru yang menjadikan seseorang berpikir akan dirinya dan kehidupan kelak dimasa datang.

\section{Daftar Pustaka}

Ma'arif, DR. Bambang.S. 2010. Komunikasi Dakwah Paradigma Untuk Aksi. Simbiosa Rekatama Media. Bandung

Rahmat, Jalaluddin. 2003. Psikologi Komunikasi. Remaja Rosdakarya. Bandung

Sabiq, Sayyid. 2014. Ringkasan Fikih Sunnah. Beirut Publishing. Jakarta 